UDC 378.14:04

Dolynskyi Yevhen Volodymyrovych

$\mathrm{PhD}$ in Pedagogic sciences, Associate Professor

Associate Professor at the Department of translation

Khmelnytskyi national university, Khmelnytskyi, Ukraine

dolynskyi@mail.ru

\title{
THE ANALYSIS OF SCIENTIFIC RESEARCHES CONCERNING EDUCATION INFORMATION TECHNOLOGIES SYSTEMS IN HIGHER EDUCATION INSTITUTIONS
}

\begin{abstract}
The role of information technology in education is exploring the potential for technology to redefine the terms of teaching and learning. Introduction information technology in education, effects of the continuing developments in information technology (IT) on education. With the help of IT now it is easy to provide audio visual education. Now with this vivid and vast technique as part of IT curriculum, learners are encouraged to regard computers as tools to be used in all aspects of their studies. In particular, they need to make use of the new multimedia technologies to communicate ideas, describe projects, and order information in their work. IT has provided immediacy to education. Now in the year of computers and web networks the pace of imparting knowledge is very fast and one can be educated anywhere at any time. Elearning professionals are constantly looking for new ideas and for successful online learning solution, especially cost-effective. The open source software community claims to have a great, low-cost system for learning management or course management. It is called Moodle, and it may be well worth your consideration.
\end{abstract}

Keywords: information technology, educational training, E-learning, Moodle-environment.

Introduction. Information and communications technology (ICT) is an extended term for information technology (IT) which stresses the role of unified communications and the integration of telecommunications (telephone lines and wireless signals), computers as well as necessary enterprise software, middleware, storage, and audio-visual systems, which enable users to access, store, transmit, and manipulate information.

In the technological era, IT aids plenty of resources to enhance the teaching skills and learning ability. Information technology has the ability of speeding up information delivery, so this ability can be used in improving our education environment. With the implementation of Information Technology, costs of accessing educational material are cut down and it makes it easy for students to learn from anywhere. New technologies are changing the way we learn and they have also changed the process of teaching. Both teachers and students are using these new educational technologies to archive specific academic goals. The only challenge is that Information Technology comes at a cost, so those who cannot afford the price tend to have difficulties to benefit from the opportunities of Information Technology in education.

Theoretical basis and research methods. Among pioneers in research of the future teacher training in the society informatization conditions was M. I. Zhaldak, who in due time suggested the teacher's preparation to information technologies usage in educational process system (Zhaldak M. I., 1994). A notable phenomenon is the world and domestic science's accumulation of considerable IT work experience in teaching math, computer science, physics etc. Still valuable are works of M. I. Burda, A. F. Verlan', B. S. Hershuns'ky, V. I. Lapins'ky, N. V. Morze, Y. S. Rams'ky which have a lot of scientific potential. If we come back to the future teacher's preparation to IT usage in educational process problem, it should be noted that it was highlighted in scientific works of V. P. Bespal'ko, V. Yu. Bykov, A. M. Hurzhiy, M. I. Zhaldak, N. V. Morze, M. L. Smul'son. Our determination of relevance and necessity of future human sciences teachers' education system as a separate problem points out the obligation to use the beforementioned scientists' works as a guide. 
The aim of investigation. Thus. The aim of this article is to highlight the modern educational model, which is based on software, distance learning and is described in many scientific researches.

Summary of the main material. We agree with M. I. Zhaldak in particular; according to him, the task of diverse IT usage in scientific educational process shouldn't be reduced to the classes being full of computers and educational programs only. The education's informatization significantly pushes forward the solution of its humanitarization problem. This is because one of the most important humanitarian problems are human communication, providing access to knowledge, receiving of timely, reliable and comprehensive information, prediction of decisions taken' consequences, preserving and defending of environment and social system functioning (Zhaldak M. I., 1994).

Marcel Lebrun (2011) studied the impact of the ICT on the quality of the students learning and the professional development of the teachers of the superior. He raised that technologies are certainly carrying potentials for the teaching development but, in order to withdraw the hoped educational values, they need to be supported by pedagogical devices based on more attractive and interactive methods, supported by new roles of actors, teachers and students. And finalized in the development of human, social and professional skills of these actors (Lebrun M., 2011).

Indeed, education's informatization is not only the appropriate equipment (such as computers, other computer-oriented devices, computer classes) installation in educational institutions (Lapins'kyi V. V., 2008). This idea was confirmed in V. V. Lapins'ky's researches: «We cannot hope that because of the most innovative education devices including electronic training manuals and interactive boards there will happen a fast and effective modern education technologies implementation of absolutely all subjects. The necessary condition of the effective most modern educational means usage is the appropriate teaching methods development and providing every teacher with them» (Lapins'kyi V. V., 2008).

The Russian scientist V. V. Hrinshkun's works are valuable scientific developments in the search of ways to solve the problem stated above. He also acknowledges that any experienced teacher would confirm: against of backdrop of pretty positive information technologies implementation effect in many cases the informatization means usage has no effect on increase in educational efficiency, and in others its effect is negative.

The conducted scientific researches show that besides aforementioned scientists, the future teacher training problem attracted and attracts now both Ukrainian and foreign scientists.

For example, I. M. Bohdanova suggested a professional teacher training renovation model as a wholesome science-methodical providing system which consists of 4 components: conceptual, structure-informative, technological and organization-didactical. Her dissertation contains theoretic and practical research of the professional teacher training renovation process according to the module approach to education and with the help of computer management means. The development tendencies and regularities of new interdisciplionary research direction, pedagogical innovatics and its specific branch, technomatics are revealed in her work. I. M. Bohdanova proves that aforementioned model's realization is provided by the appropriate professional teacher training renovation technology which can be broken down to: experience modeling, i. e. the description of what we want to achieve; practical model approbation; procedural experiment analysis, his adjustment in the work process; practical model checking giving the correctives; preparation of suggestions for broad implementation. The main way to achieve the anticipated results became the informationmodular technology which the scientist presented in the form of informational and modular education technology complex. 
The research of future teachers' preparation to innovative professional practice forming theoretic-methodological basis was conducted by I. V. Havrysh, the scientist who works in H.S. Skovoroda Kharkiv National Pedagogical University (Havrysh I. V., 2002). The author presented a theoretical generalization of the main scientific dissertation ways to solve the contradiction between the urgent need in future teachers' innovative professional activity preparation improvement and insufficient level of aforementioned process' theoreticmethodological and technical implementation development. In our opinion, suggested by the author new approach to solving the complex problem of how to form social-pedagogical future teachers' readiness to create, implement and distribute educational innovation is of great importance.

In her work I. V. Havrysh mentions that in the process of implementing the new educational paradigm into general education institutions' practical activities a real contradiction arose. On the one hand, we have legislative guaranties and scientific innovative modern schools' problem solution provision; on the other hand the level of pedagogical staff readiness to professional activity in the Ukrainian general secondary education system modernization conditions is not high enough. The scientist found out that the future teachers' readiness to innovative professional activities forming issues have already made it to the thematic field of pedagogical innovators as a science about educational field's innovative processes. At the same time she established that the present state of aforementioned problem development is characterized by coexistence of different approaches to its solution and ambiguity in the main categories and key principles' interpretation. It also has been established that traditional approaches to higher education and training process organization do not fully satisfy the modern needs in systematic preparation of future teachers to create, implement and distribute educational innovations. This is why the author proved the expediency of special student education organization which would be aimed at them becoming the educational innovations subjects. In pedagogical innovates this was labelled as «innovative education». "According to the general and specific future teachers innovative professional activities preparation regularities the system of appropriate principles has been established. It consists of: general didactic principles which are caused by the innovative education regularities as a part of general high pedagogical educational institutions' students preparation (principle of innovative education content correspondence to the general innovative pedagogical activity structure, dialectical monism; dialectical programmed and adaptive management unity; provision of all conditions needed to achieve innovative education goals, feedback, organic unity of general, specific and individual components in future teachers innovative education, functional innovative students education content completeness) and principles caused by regularities of future teachers' becoming process as the innovative professional activity subjects (principles of innovative, personal-activistic, formational and civilization approaches)» (Havrysh I. V., 2002).

For example, foreign (Moroccan) researches have made the exploration of the problem while trying to study the impact of the use of the ICT on the teaching-learning of the scientific disciplines and in particular physics.

Thus A. Bouchaib and N. Benjelloun worked out - in a fundamental way- an inventory of the conceptual difficulties observed in the students of the first university cycle in the field of electrostatics. They integrated the resources of the site «University online» (UeL) in a teaching session in présentiel. The results showed that when the resources of UeL are integrated in situation of self-learning accompanied by a tutor teacher, they allow a good appropriation of these concepts and a better interpretation of the situations used like instrument of evaluation. These researchers also reported that a teaching session, enriched by UeL is tiring for a facilitator teacher who must ensure only a technical and conceptual support for the students and follow the progression of the learning of the group. It is beneficial only 
for restricted groups; the facilitator teacher should give each student a minimum time for an effective learning (Bouchaïb A. and Benjelloun N., 2011).

W. Berrada and S. Chraïbi conducted a comparative study between two educational experiments remotely conducted in two Moroccan academics (Engineering School and Faculty of Science). Both devices proposed are based on a social constructivist pedagogy promoting a student-centered learning. These researchers concluded that the progressive and dynamic integration of a learning environment could facilitate the appropriation of courses by students of their institutions and thus contribute to reducing the rate of failure and abandonment. These experiments have identified some difficulties of technical, organizational and pedagogical sides (Berrada W. and Chraïbi S., 2010).

In the National Pedagogical Dragomanov University O. M. Honcharova conducted a research of personality-oriented economic professions students' processing competencies system formation theoretic-methodical basis (Honcharova O. M., 2007). The author revealed the problem of high education institutions economic majors' educational process informatization and highlighted the economic staff preparation practice. On the basis of informatics preparation future economists development problem modern state analysis, content of human society and education in general commission for informational culture forming, economics students' informational and communicational competencies were developed the main components of personality-oriented methodical informational preparation system for future economists in universities (Honcharova O. M., 2007).

In the Taras Shevchenko National University of Luhansk V. V. Dokuchayeva conducted a research of theoretic-methodological innovative pedagogical systems designing grounds. The author points out: «The general renovation process makes the Ukraine's reaching of absolutely other development level possible today already. That's why the role of formative subject which can produce strategies for future progressive transformations is especially actualized» (Dokuchayeva V. V., 2007).

In her work Y. M. Smyrnova-Trybul'ska proves that one of the primary education development direction is information and communications technologies implementation in all educational system's sections. She proves that it would provide further influence on educational process effectiveness, youth training and development, education's accessibility and quality, young generation's preparation for life in informational society etc. (SmyrnovaTrybul'ska Ye. M., 2008).

The theoretic-methodical basis formulation of informative natural sciences teachers in the e-learning field competences formation made it possible for her to determine that the problem has risen, i. e. scientific-methodical teaching and learning process provision principal modernization, appropriate IT teachers preparation, implementation of innovative education technologies which are concretized in the new informational, pedagogical, modular and remote education technologies. We think that what valuable is the selection of contradictions between accumulated but non-systematic remote technologies realization in the high and postgraduate education systems experience and insufficient theoretical basis and computeroriented remote studying methodical systems development. One of the problems Y. M. Smyrnova-Trybul'ska sees in determining the organizational-pedagogical and technological conditions complex for realization of remote studying in the high and postgraduate education system. Another important contradiction and problem which needs to be solved is insufficient teachers' competence level (futures ones and those who are already working) to use IT and remote studying education forms which are based on IT-technologies in their professional activities. At the same time there is a great need to increase this level in the shortest terms because of the education system modernization and with its informatization the emergence of new modern requirements to teachers' competence in IT field and remote studying (Smyrnova-Trybul'ska Ye. M., 2008). 
The forming of future translators professional training using ICT, remote studying technologies was the subject of dissertations by: O. V. Shupta (the forming of future translators' readiness for professional creative activity), A. M. Yankovets' (preparing future translators with the means of informative-communicational technologies), O. O. Matsyuk (the forming of future translators' professional competence using the means of informativecommunicational technologies), Y. V. Dolyns'ky (the forming of future translators' communicative competence with the means of remote technologies).

According to A. M. Hurzhiy with whom we agree, among the reasons which slow down IT usage in translation teaching are the psychologically-pedagogical problems. They lie in the low level of future translator's readiness to use IT, absence of scientifically proved ICT usage in educational process methodologies.

Ye. Polat, I. Robert, V. Soldatkina and others conclude that information and communications technology in the educational process is not only the use of multimedia tools and Internet technologies at the lectures, seminars, practical lessons, libraries computerization but also the creation of the information-educational environment which provides the fulfilling of different information needs for those who teach and those who are being taught (Kartashova L. O., 2012).

Such Ukrainian scientists as N. Klokar and M. Skyba single out the term «information and educational learning environment» and interpret it as an information environment in which occurs personally-oriented educational process which in its turn is being characterized by certain criteria of its appreciation, clear description of its results and achievement methods.

Such researches as V. Izvozchykov, G. Sokolova, O. Tumacheva suggest the term «information and educational learning environment», which is being viewed by them as a construction that corresponds the practical human needs and appears in the following main forms: physical space, where common teacher training and educational activity with the use of the modern information and communication systems, tools and educational technologies occur; virtual hypertext network, semantic concept relations and thesauruses (Havrysh I. V., 2002); hierarchical pedagogical and educational systems and spaces in the global, regional and local dimensions.

In his research R. Pavlyuk uses the term «virtual pedagogical environment» which, on his opinion, provides a creative cooperation process of the education members, «in which the means of that kind of reality creation is an involvement of all education technologies which stimulate the development of creative imagination, fantasy, that is all individual potentials further development activation» (Kartashova L. O., 2012).

$\mathrm{V}$. Moyseyev suggests understanding information computing environment as «...the only information-educational space built with the help of the information integration on the traditional electronic media and computer-telecommunication cooperation technologies. It may contain virtual libraries, distributed database, structured educational and methodological complexes and extended didactics apparatus in which new pedagogical principles functionate».

Today the «World Wide Web» technology is another user-friendly service for educational process - information service of global area network which is built on hypertext and means of its transmission (protocols). WWW is the environment for information interchange between the people, which is developed on the basis of different hypertext documents that consist of components with various ways of information supply (text, sound, graphics, three-dimensional objects etc.), besides every element can be a reference to another document or its component. Client programs of WWW (browsers, navigators) interpreter such references and display data of hyper documents for users and corresponding services (ftp, gopher, Usenet, e-mail etc.). Thus, WWW service is freeware and versatile for many Internet services, and the system itself plays integrant part. We distinguished «Web 2.0» services as: 
1) Social research networks - systems, which allow users to choose themselves the way of researching, sites and words they look over first, and how to present the found results (for example http://company.quintura.com/ru/);

2) Means for marks saving - online service for saving references of web-page which allows to add references from any connected to the Internet computer; to get access to them from any connected computer; to mark tags to references (marks of category), which make it easier to find them some time later ( for example http://www.google.com/ bookmarks/);

3) Social services for multimedia servers saving - make possible free saving, classifying, digital photo exchange (http://picasaweb.google.com), audio-(http://www. podcaster.org.ua, http://rpod.ru) and video- (http://youtube. com) records exchange, text files exchange (http://docs. google.com), presentations exchange (http://www.slideshare. net, http://docs.google.com), books exchange (http://www. google.com/books, http://www.scribd.com), and also to set up discussions of the content;

4) Network diaries (blogs) - Internet service that makes possible to any user to keep records of any theme he likes (for example blogger.com, wordpress.com, educational blogosphere - http://blog.classroomteacher.ca, http://www. openclass.ru, http://edublogs.org);

5) WikiWiki - social service that makes possible to any user to edit the site text (write, make changes, delete, make references for the new articles); different variants Wiki software allow to load pictures, files that contain textual information, video-fragments, audio file etc. (for example Wiki Engines - www.mediawiki.org, Wiki-Project http://uk.wikipedia.org, http://www.letopisi.ru/);

6) Mind maps - means for rendering of general thinking with the help of schemes (for example http://bubbl.us, http:// freemind.sourceforge.net, https://www.mindmeister.com);

7) Social geo-services - Internet services which allow finding, marking, commenting, and adding photos to objects on the Earth map with the high accuracy. In such conditions we use actual data received by Earth satellites (for example http://maps.google.com, http://wikimapia.org);

8) Social networks - communities of people linked by joint interests or communication need;

9) Recommendation services - systems which are specialized in the one type of content (books, movies, music etc.), and their users do the work of experts specifying the most interesting position;

10) Mash-ups - web-services which unite data from several sources in one integrated instrument;

11) Virtual worlds - are 3D-spaces with certain characteristics (for example: multiuser game), which give possibility for information environment creation (Osadchiy V. V., 2011).

The developers of the Khmelnitskyi Naional University integrated information system «Electronic university» prove that the main result of the educative and modern university management activities computerization is a development and implementation of the information-computing university environment, which must contain two functional subsystems: «Information Database» and «Modular Environment for Studying».

So, the great value in the solving of problems connected with specialists training efficiency increase has a providing of all educational institution information resources integration into one system and the formation of the electronic education informationcomputing environment. For this purpose the information-computing environment subsystems are implemented in the Ukrainian universities, examples are:

Khmelnytskyi National University - «Modular Environment for Studying» (https://msn.khnu.km.ua); Kherson State University - Distance Learning System «KSU Online» (http://ksuonline.kspu. edu/?lang=uk); Ternopil Volodymyr Hnatyuk National Pedagogical University - «Electronic Courses Server» (http://elr.tnpu.edu.ua/mod 
/forum/discuss.php?d=11); Chernivtsi National University - Electronic Learning Site «elearning» (http://e-learning.chnu.edu.ua/); National Pedagogical Dragomanov University «Electronic Pedagogics» (http://www.moodle.npu.edu.ua/);- «E-environment» (http://elearning.kubg.edu.ua/login/index.php); The Kirovohrad Volodymyr Vynnychenko State Pedagogical University - «Our Moodle» (http://moodle.kspu.kr.ua/); Zaporizhzhya National University - «Electronic learning software system» (http://moodle.znu.edu.ua/).

Unfortunately, there are negative examples of the big and famous universities where where these systems are not implemented. We hope, this situation improves in good time. The mentioned systems are more or less developed on the learning management with open source code Moodle (Modular Object-Oriented Dynamic Learning Environment). According to its functional possibilities, exploration simplicity and convenience of using this software meets all the requirements as for the electronic learning system (Kartashova L. O., 2012).

Surveys describe a variety of advantages and disadvantages for using Moodle. Supporters highlight important advantages, such as: lower total cost for ownership; higher levels of security; peer review; greater flexibility; ability to customize by modifying code; audit ability and code availability; technical support; well-tested updates and plug-ins; variety of capabilities and tools.

Many say that cost saving is not the key Moodle advantage, but it is rather access to various innovative tools that interface with the Moodle platforms. Moodle is available in many languages thereby greatly increasing the reach to the LMS to educators everywhere. Anyone (students and teachers alike), can choose to view a Moodle site in a different language simply by selecting the language from drop-down menu on the upper-right corner of the screen. For example, if you choose Ukrainian, the interface of the site will change into that language. Educators can easily enhance learning based on local preferences.

Conclusions. Thus, there are several advantages of enrolling in online courses such as convenience, flexibility, and accessibility. Online students can easily access programs and experts without the need for relocation. At the Moodle courses are accessible from anywhere, students can structure their study time around other job or family-related responsibilities. Other possible advantages are streamlined courses; condensed, accelerated degree programs; diversity of peer groups; student-centered teaching approaches; and integration of innovative instructional technologies. However, there are several challenges with online learning due to limited face-to-face personal interaction between students and instructors. Many sources attribute high students attrition in online courses to the lack of interaction between participants in courses taught in the distance education environment. Researches suggest that students in distance learning programs should be socially and academically integrated in order to provide meaningful learning experience.

\section{REFERENCES}

Bouchaïb, A. \& Benjelloun, N. (2011). «Impacts des TIC sur l'enseignement et l'apprentissage des conceptions relatives au champ électrostatique en classes préparatoires aux grandes écoles d'ingénieurs (CPGE)». Revue internationale des technologies en pédagogie universitaire, 8 (3), p. 66-80. Available on the site of the review : http://www.ritpu.org.

Berrada, W. \& Chraïbi, S. (2010). "Comparaison d'expériences d'insertion de dispositifs technopédagogiques dans le milieu universitaire marocain». Communication présentée au 26ème congrès international de l'Association internationale de pédagogie universitaire (AIPU): réformes et changements pédagogiques dans l'enseignement supérieur à la faculté des sciences de l'éducation, Rabat, Maroc. 
Dokuchayeva $\boldsymbol{V}$. V. (2007) "Theoretical-methodological basics of designing innovative educational systems». (Unpublished candidate dissertation). Luhans'k, Ukraine: Tarasa Shevchenko LNPU (in Ukrainian).

Havrysh I. V. (2002) «Evolution of pedagogical education values in the USA». Modern problems of education and arts methodological aspects, 2002, 31-41 (in Ukrainian).

Honcharova O. M. (2007) «Theoretical-methodical bases of personally oriented system of formation the information competence of economic specialties students». (Unpublished candidate dissertation). Kiev, Ukraine: M. Drahomanov NPU (in Ukrainian).

Kartashova L. O. (2012) "The system of information technology training of humanitarian specialties students of higher pedagogical institutions». (Unpublished candidate dissertation). Instytut pedahohiky NAPN Ukrayiny (in Ukrainian).

Lapins'kyi V. V. (2008) "Educational environment of new generation and its components». The scientific journal. (6th ed.), 26-32 (in Ukrainian).

Lebrun M. (2011) "Impacts des TIC sur la qualité des apprentissages des étudiants et le développement professionnel des enseignants: vers une approche systémique». Revue des Sciences et Technologies de l'Information et de la Communication pour l'Education et la Formation (STICEF), 18. Available on the site of the review : http://sticef.univ-lemans.fr

Osadchiy $\boldsymbol{V}$. V. (2011) «Mobile learning technologies in professional training of future teachers». Modern information technologies and innovative teaching methods in training: methodology, theory, experience, problems, 6, 121-126. (in Ukrainian).

Smyrnova-Trybul'ska Ye. M. (2008) "Theoretical-methodical bases of formation the information competence of natural sciences teachers in the field of distance learning». (Unpublished candidate dissertation). Kiev, Ukraine: M. Drahomanov NPU (in Ukrainian).

Zhaldak M. I. (1994) «The humanitarian potential of Informatization. UDPU, 32, 3-20 (in Ukrainian).

\title{
АНАЛІЗ НАУКОВИХ ПОГЛЯДІВ НА РОЗВИТОК ІНФОРМАЦЙННО- ТЕХНОЛОГІЧНИХ ОСВІТНІХ СИСТЕМ У ВИЩИХ НАВЧАЛЬНИХ ЗАКЛАДАХ
}

\author{
Долинський Євген Володимирович \\ Кандидат педагогічних наук, доцент кафедри перекладу \\ Хмельницький національний університет, м. Хмельницький, Україна \\ dolynskyi@mail.ru
}

\begin{abstract}
Анотація. На сьогодні, роль інформаційних технологій (IT) в освіті є досить значним, що спонукає до перегляду педагогічних умов викладання i навчання. Імплементація інформаційних технологій в освіті є наслідком розробки освітніх інформаційних продуктів, що покращують якість навчання. За допомогою дистанційних технологій, можна легко забезпечити аудіо-візуальну освіту. Головним елементом у навчальному процесі постає комп'ютер, як інструмент, що може використовуватися у всіх аспектах дослідження. Зокрема, повинні використовуватися хмарні мультимедійні технології, щоб передавати ідеї, опис проектів, готові домашні завдання. Це забезпечило потребу в неперервній освіті робить іiі доступнішою. В статті описується процес навчання, за допомогою дистанційних технологій, що може бути налагоджений у будь-якому місці в будь-який час. Зазначається, що фахівці є постійно у пошуку нових ідей для удосконалення електронного та он-лайн навчання. Найпоширенішою системою дистанційного навчання, що використовується в українських ВНЗ є система Moodle, за допомогою якої можна створювати різні дистанцій курси.
\end{abstract}

Ключові слова: інформаційні технології; дистанційне навчання; електронна система Moodle, електронне освітнє-середовище 